\title{
潜在的な航空旅客負荷にみる新幹線途絶による影響の基礎的検討* Basic study on latent air passenger demands caused by stopping of the Shinkansen*
}

\author{
谷口守** 阿部宏史 $* *$ 清水健夫*** \\ By Mamoru TANIGUCHI**, Hirofumi $\mathrm{ABE}^{* *}$ and Takeo SHIMIZU***
}

\section{1. 研究の背景と目的}

昭和 39 年に東海道新幹線が開通して以降、わが国の 地域間交通において新幹線は大きな役割を果たしてきた。 大容量で安全性、信頼性の高い交通施設である反面、近 年ではその基盤施設の老朽化や酷使等に伴って様々な問 題が発生してきている。近年大きく取り上げられるよう になったトンネル内でのコンクリート塊崩落といった目 を引く問題のみならず、施設全体のリニューアルを視野 に入れた議論も必要な時期になってきた。

その一方で、新幹線が地域間交通に果たす役割につい て冷静に議論される機会は今まで々しかった。その中で も、施設更新を含む特定地点での途絶時に、新幹線によ る都市間旅客者に旅行のとりやめ、延期、経路、手段変 更までも含めてどのような影響が総量として生じ得るか という基礎的な問題について、十分な検討はなされてい ない。本研究では具体的に新幹線ネットワーク上に 7 カ 所の途絶地点を想定し、各場合において航空旅客に及ぶ 潜在的な影響を明らかにすることを目的とした。このよ うな方法を採用することによって、新幹線途絶の影響を、 顕在化した交通にのみ着目して分析を行った場合よりも、 より包括的にもれなく捉えることが可能となる。

なお、本研究は新幹線途絶時に実際に生起寸る交通パ ターンを予測することを意図するものではない。あくま で途絶による影響をすべて潜在的な航空旅客数という一 つの軸上に換算・投影することにより、その影響の大き さを簡便に比較できるようにすることを目的としている。

以下、2.で従来の研究と本研究の特徵、3.で分析の手 順と使用データ、4.で途絶による影響に関する分析結果、 5.で実際の途絶時に顕在化した航空便サービスとの結 果の比較を行い、6.において本研究で得られた成果と今 後の課題をまとめる。

\section{2. 従来の研究と本研究の特徵}

地震による災害に着目し、交通ネットワークの途絶の 影響や可能性について検討した研究は数多い。特に道路 *キーワード:鉄道計画、空港計画

**正会員 工博 岡山大学環境理工学部

(岡山市津島中3-1-1 Tel.Fax086-251-8850)

***学生員 航空大学校
交通については地域幹線道路の経路代替性 ${ }^{1)}$ 、地区レ ベルでの道路の信頼性評価党の分野などにおいて多くの 研究成果が積み上げられている。鉄道ネットワークを対 象にしたものや、国土レベルでの議論を念頭に置いた研 究は少ないが、地震による途絶を確率的に捉え、道路な ども含めた旅客交通流動全体が受ける影響を検討した研 究3)など、計画上有益な知見が既にいくつか示されてい る。

これらの研究は、基本的にはいずれも確率的な観点か ら交通ネットワークの評価を行おうとするものである。 それに対し、本研究では従来取り上げられる事の無かっ た新幹線の途絶のみを対象事象とし、途絶箘所を確定的 に決めた場合に潜在的な航空需要に及ぶ影響を各空港に かかる負荷として予測するものである。具体的な研究の 特長としては、下記のような諸点があげられる。

1)純流動データを用いるため、真の出発地・到着地に基 づく潜在航空旅客がもたらす負荷について言及でき る。

2)このことは即ち、新幹線と航空機の競争関係のみなら ず、補完関係(空港まで新幹線を代表手段としてアクセ スし、そこから飛行機に乗るような行動）についても 考慮できる。

3)モデルを構築しなくとも、各個人が選択する空港は居 住地や目的地ゾーンごとに既存データから特定でき る。このため、LOSデータ収集を行わなくとも簡便で 途絶による潜在的な影響を高精度で分析することが 可能である。

\section{3. 使用データと潜在航空旅客負荷算定の手順}

(1) 使用データ

分析に使用したデータは、平成 7 年度幹線旅客純流動 調査である。この調查は、「通勤・通学以外の目的で日 常生活圈を越える(府県をまたぐ)旅客流動を対象に、平 成 7 年秋期の平日 1 日をべースに実施されたものである。 本研究では、このうち「航空」旅客及び「幹線鉄道」旅 客データを分析に用い、新幹線利用者については「幹線 鉄道」旅客データより利用者の新幹線駅コードをもとに 抽出を行った。また、ゾーニングとして、分析では調査 で設定されている全国207ゾーンを主に利用した。 


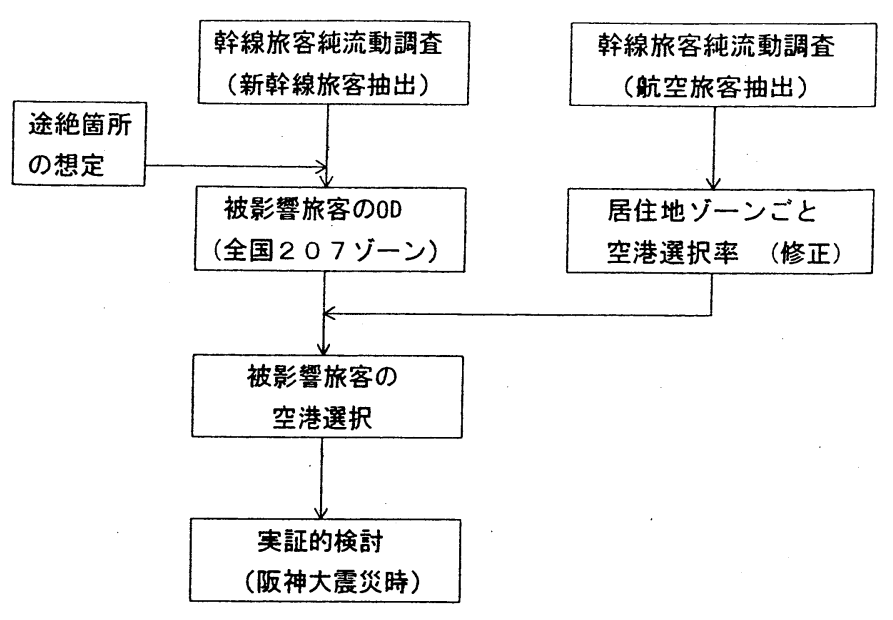

図-1 分析手順の概要

\section{（2）潜在航空旅客負荷の算定手順}

負荷の算定は図一 1 に示す手順で実施した。基本的な 考え方としては、まず、途絶によって影響を受ける（そ の途絶箇所を通る）新幹線旅客を抽出する。これら抽出 された新幹線旅客を航空機を交通手段として選択するな らば、どの空港を発地、着地として選択するかを特定し た。その特定方法は、実際の航空旅客の空港選択情報を 207ゾーンごとに集計することによって推定を行った。

想定した途絶箇所は山陽新幹線で 3 力所 (広島・新岩 国間、新倉敷・福山間、新大阪 - 姫路間) 、東海道新幹 線で 2 力所 (岐阜羽島・米原間、掛川 - 浜松間)、東北 新幹線（郡山・福島間）、上越新幹線（上毛高原・越後 湯沢）各 1 力所の計 7 力所とした。

途絶によって影響を受ける新幹線利用者が、潜在的な 航空旅客となるかどうかについては、遠距離トリップに ついてはすべて潜在的な航空旅客としてカウントし、近 距離トリップにおいてはすべて自動車や在来線に転換し て潜在的な航空需要にはならないものと仮定した。ここ で近距離とは、小山・新横浜間など発側と着側で同一空 港選択 (この場合はどちらも東京) となる場合と定義し、 遠距離とは近距離の定義に当てはまらないものすべてを 指すこととした。

注意が必要な点として、本研究ではあくまで途絶によ って生じる潜在需要全体を航空旅客への負荷と仮想して 分析を行っていることである。ここで述べる航空旅客の 負荷の中身には、新幹線が途絶することによって航空機 利用へと転じた顕在化した需要の他に、旅行それ自体を 取りやめたり、復旧後に延期したケースや、長距離移動 であっても適当な航空便が設定されていないことによっ て自動車利用に転じたトリップもすべて含まれている。 このような捉え方をあえて行ったのは、途絶による新幹 線旅行者一及んだ影響を顕在化したものだけに着目して 検討しようとすると、途絶が持つ意味を評価するという 観点からは事実上過小評価になってしまうためである。 寸なわち、影響者総数という観点からの検討が必要であ
り、本研究ではそれを負荷として捉えている。新幹線途 絶の際に生じる潜在航空需要は、実際にその都市間で航 空便が設定されているかどうか、また、機材スケジュー リング上実際に航空便が設定できるかどうかという点と は無関係に発生するものである。換言すれば、本研究で 得られた潜在的な航空旅客負荷は実際の途絶時における 顕在化した航空旅客量と一致するものでは全くなく、ま た、本研究の性格上、一致させることを目指すものでも ない。すなわち、途絶によって影響を受けた旅客が実際 にどのような交通機関を利用したか、もしくは旅行を取 りやめたかどうかは、本研究の興味の対象ではない。こ のように、本研究は新幹線途絶による影響を、変更行動 として顕在化しない者まですべて含めた潜在負荷として 検討することで、今後の新幹線の補修計画や関連する空 港整備への有効な情報提供を行うことを目指しており、 顕在化する旅客数を求めようとする従来の航空需要予測 とはそもそも全く目的が異なる研究であることに留意が 必要である。

また、大都市圈など複数の空港を持つエリアに関して は、分析上複数の空港を一つの空港としてまとめて扱っ ている。例えば、本研究では羽田空港と成田空港を合わ せて東京空港と呼び、同様に関空と伊丹空港を合わせて 大阪空港、広島空港と広島西空港を合わせて広島空港と 定義し、その利用の内訳については区別せずに併せて取 り扱うこととする。

\section{4. 分析結果と考察}

特定の途絶箇所について先述した分析手順に沿つて算 定を行うと、まず各空港間での潜在航空旅客の数が明ら かになり、その值を空港毎に合計すると各空港の潜在航 空旅客数を求めることができる。同じ空港間・空港でも 往復・発着で若干異なった值が得られるが、航路につい ては往復の合計值、空港については発着の合計值を空港 にかかる潜在負荷とした。特に断らない限り、単位は(人 /年)上する。

以下の考察では、まず、 7 カ所の途絶箇所の中から代 表事例として新大阪・姫路間途絶の場合を取り上げ、そ の主要空港間での潜在航空旅客による負荷について(1) で考察する。さらに、それらを空港ごとに集計した結果 について(2)で考察する。最後に途絶箇所の違いによる各 空港への影響の差異について(3)で検討を行う。

\section{(1) 主要空港間での潜在旅客負荷}

新大阪・姫路間で途絶が生じた時に、各主要空港間で 発生する潜在航空旅客負荷を図一 2 に示す。この結果か ら、広島・大阪間での負荷が最も大きく、福岡・広島間 がそれに次いでいることがわかる。また、広島・東京間 や福岡・東京間の負荷も小さくはないが、すでにこの都 市間ではもともと航空便のシェアが大きいこともあり、 旅客は前 2 者の航路ほど潜在負荷は大きくならない。 


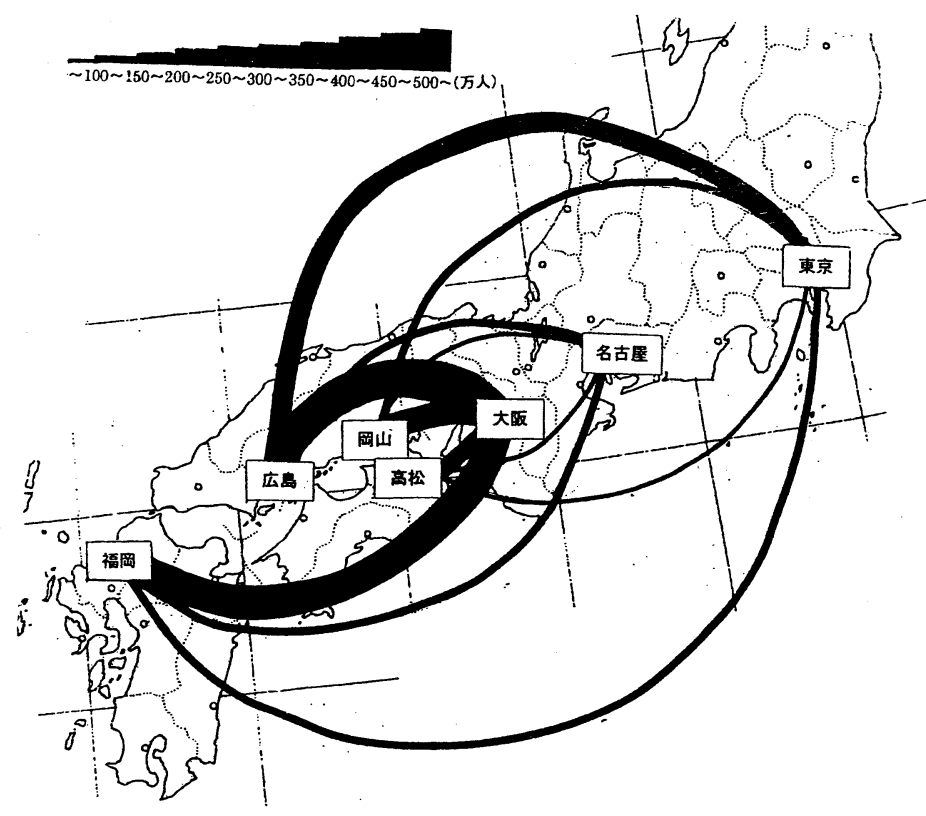

図一2 新大阪・姫路間途絶時における主要空港間 に発生する潜在旅客負荷（実数、発生集中計）

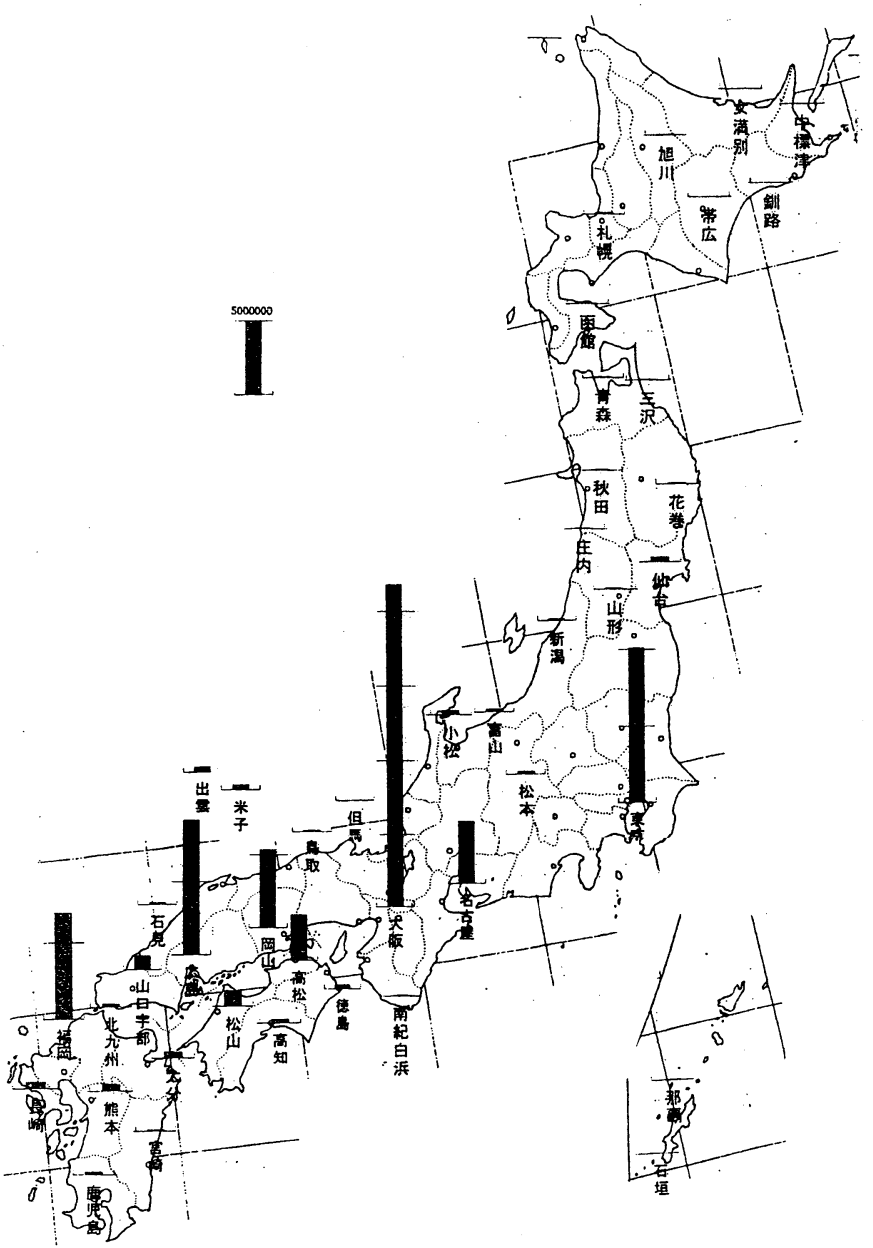

図一３新大阪・姫路間途絶時における各空港に発 生する潜在旅客負荷（実数、発生集中計）

\section{（2）各空港における潜在旅客負荷}

(1)の数值を各空港ごとに集計した結果を図ー 3 に示 す。空港レベルでみると、新大阪・姫路間途絶時に最も

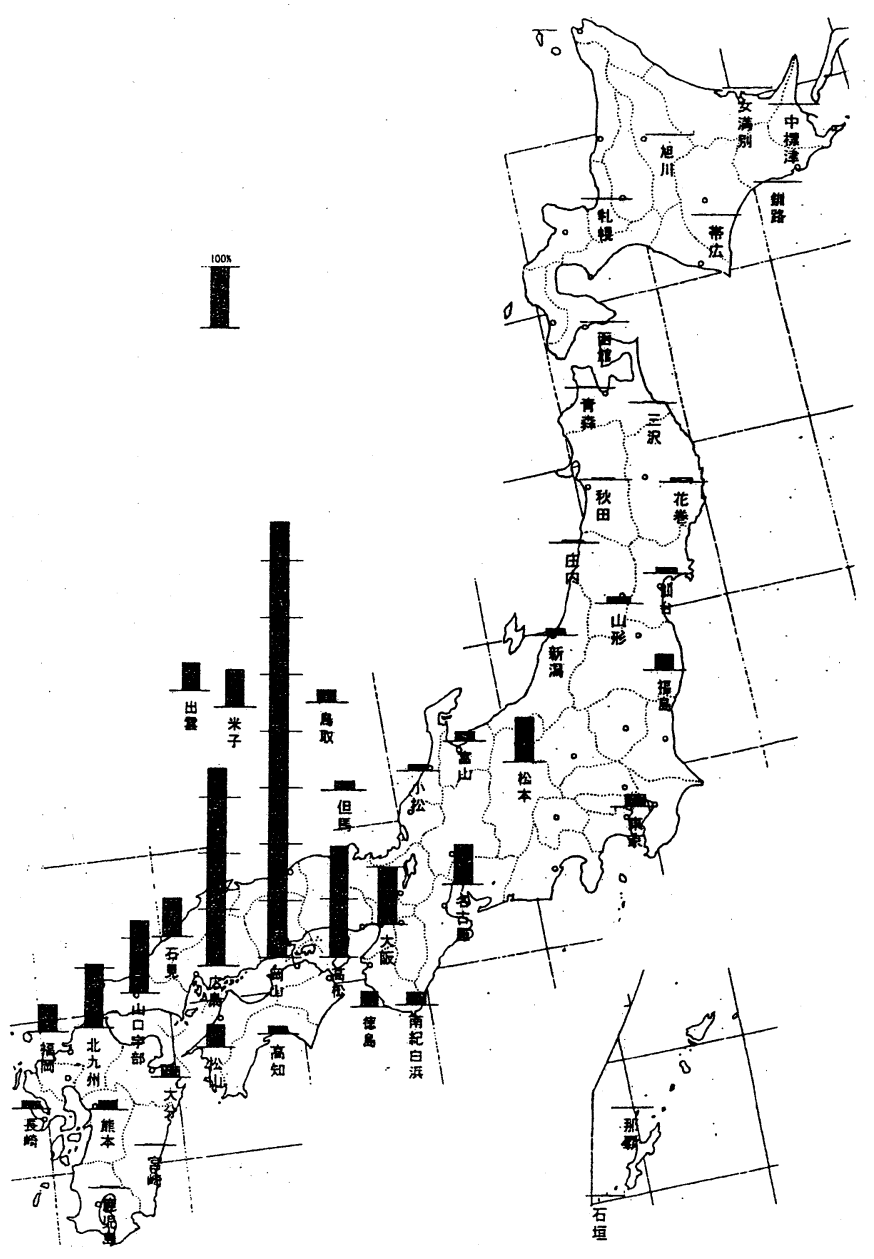

図-4 新大阪-姫路間途絶時の各空港での潜在旅客負 荷(現空港利用者数に対する比率、発生集中計)

大きな潜在航空旅客負荷がかかるのは大阪空港であり、 その值は年間 2,000 万人を超える。これに次いで東京、広 島、福岡、岡山の各空港での值が高くなっている。途絶 地点から離れた四国や九州の地方空港においても潜在航 空旅客負荷が生じることがこの図から読みとれる。

また、このような実人数べースでの潜在負荷の検討に 㞦え、それがその空港の規慔から判断してどれだり負担 になるのかという点に関しては別の観点からの議論が必 要になる。図一 4 には、図一 3 で示した潜在航空旅客負 荷（実人数）を、各空港の実年間利用者数で割った值を 示した。この值が大きければ、たとえ潜在航空旅客負荷 の実人数值が小さくとも、その空港が普段さばいている 旅客数と比較して大きな潜在負荷がかかることを意味し ている。この図から、図一3で潜在航空旅客負荷の実人 数值が大きかった大阪や東京では、その大きさは通常そ の空港でさばいている旅客数程度以下であることがわか る。これに対し、岡山では通常の 7 倍以上、広島で 3 倍 以上、高松で 2 倍程度の負荷がかかることがわかり、主 要地方空港において人数べースでははるかに大阪や東京 に及ばなくても、その実質的な影響が非常に大きくなり うることが読みとれる。 
表一 1 各地点途絶時における主要空港にかかる 潜在的客負荷（実数、発生集中計）

(万人/年)

\begin{tabular}{|c|c|c|c|c|c|c|c|c|}
\hline & & 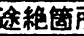 & & & & & & \\
\hline & & 㡴岛- & $\begin{array}{l}\text { 新倉数 } \\
\text { 一福山 }\end{array}$ & \begin{tabular}{|l|} 
新大䧄 \\
- 姬路 \\
\end{tabular} & 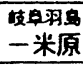 & $\begin{array}{l}\text { 質川1- } \\
\text { 浜昖 }\end{array}$ & $\begin{array}{l}\text { 郡山- } \\
\text { 福息 } \\
\end{array}$ & 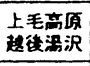 \\
\hline 空港名 & 花 巻 & & 2 & 3 & 10 & 16 & 289 & 3 \\
\hline & 仙台 & 11 & 16 & 24 & 47 & 81 & 1.159 & 28 \\
\hline & 楸 田 & 0 & 1 & 3 & 6 & 15 & 163 & 8 \\
\hline & 山形 & 2 & 3 & 5 & 11 & 18 & 238 & 42 \\
\hline & 東京 & 158 & 459 & 1.007 & 4.229 & 6.651 & 1,823 & 1,109 \\
\hline & 新济 & 2 & 5 & 10 & 26 & 42 & 15 & 889 \\
\hline & 小昖 & 5 & 13 & 25 & 100 & 95 & 4 & 51 \\
\hline & 名古屋 & 144 & 244 & 441 & 1,867 & 2.276 & 82 & 38 \\
\hline & 太阪 & 649 & 1,199 & 2,176 & 4.592 & 3.981 & 90 & 69 \\
\hline & 成取 & 4 & 5 & 6 & 15 & 7 & 0 & 1 \\
\hline & 米子 & 10 & 13 & 28 & 16 & 11 & 0 & 1 \\
\hline & 出吾 & 11 & 19 & 33 & 12 & 7 & 1 & 1 \\
\hline & 是 & 7 & 12 & 11 & 6 & 3 & 0 & 0 \\
\hline & 网山 & 80 & 217 & 536 & 202 & 146 & 3 & 2 \\
\hline & 広禹 & 433 & 1.003 & 930 & 374 & 283 & 11 & 3 \\
\hline & $山 D \neq 0$ & 156 & 120 & 88 & 31 & 20 & 1 & 1 \\
\hline & 吾松 & 36 & 94 & 306 & 75 & 50 & 71 & 1 \\
\hline & 逼㡀 & 944 & 815 & 691 & 217 & 132 & 19 & 2 \\
\hline & 合 & 2.924 & 4.507 & 6.678 & 12,071 & 14.031 & 4,338 & 2.444 \\
\hline
\end{tabular}

\section{（3）途絶箇所ごとの各空港への影響の違い}

7 力所設定した途絶箇所ごとに、各空港にどのような潜 在負荷が生じるか（実人数べース）を表一 1 に示す。こ の表より、途絶時に最も多数の潜在航空旅客負荷を発生 させるのは、掛川・浜松間途絶時であり、その数は年間 1 億人を超える。これに対し、上越新幹線（上毛高原・ 越後湯沢間）や山陽新幹線（広島・新岩国間）の潜在航 空旅客負荷は年間総数 2 千万人程度であり、本研究で想 定した途絶箇所間でも、その影響の大きさは場所によっ て 5 倍以上の差がある。

途絶による潜在負荷の発生は、いずれの途絶箇所の場 合も広く全国に及ぶ事が確認できる。一方で、その分布 は東京、大阪、名古屋など大都市の空港に集中しており、 現在の各空港の処理能力から考えて、これら潜在航空需 要を完全に処理するだけのサービスを提供することは現 実的に不可能であると考えられる。

\section{5. 実際の途絶時との比較}

本研究では上記の計算結果の特徴を検討するため、実 際に新幹線が途絶した時によ゙のような航空便の臨時サ一 ビスが実施され、潜在航空旅客の負荷に対応したかにつ いて、実データを用いて明らかにする。具体的には、実 際に新幹線の途絶が新大阪・姫路間で生じた阪神大震災

(平成 7 年) を対象とした。各航空会社（日本航空、全 日空、日本エアシステム、エアーニッポン、日本エアコ ミューター) による臨時便について、その設定状況が安 定した 3 月上半期の運行状況をすべて調べた。その際、 従来の就航便の使用機種変更も含め、機種の違いによる 定員座席数の違いも考慮し、各都市間でどれだけの座席 数が新たに確保されたかを算出した。

このようにして各空港間の新たな航空サービス（座席 数増）を算出し、それを前章で計算した新大阪・姫路

\section{表一2 阪神大震災時における臨時便データを基に した潜在航空旅客負荷の座席充足状況}

座席充足率 $(\%)=$ (臨時便総座席数) / (潜在航空旅客数 $)$

\begin{tabular}{|l|l|l|l|l|l|l|}
\hline & 岡山 & 広島 & $\begin{array}{l}\text { 山口 } \\
\text { 宇部 }\end{array}$ & 高松 & 福岡 & 熊本 \\
\hline 東京 & 121 & 22 & $*$ & $*$ & 55 & $*$ \\
\hline 名古屋 & 27 & 17 & $*$ & $*$ & 91 & 317 \\
\hline 大阪 & 30 & 37 & 41 & 19 & 58 & $*$ \\
\hline
\end{tabular}

注）往復で平均した值を用いた。

*印は臨時便の設定の無かったOD

途絶時に新たに発生する各空港間の潜在航空旅客で割る ことにより、潜在ニーズに対してどれだけの実際のサー ビスがなされたかを座席充足率として定義・算出した。 代表的な空港間での分析結果を表一 2 に示す。この表中 の座席充足率が100\%を越えるようであれば、そのODに おいては途絶による潜在負荷以上の臨時便サービスがな されたことを示す。また、この逆に $100 \%$ 以下の座席充足 率であれば、潜在負荷をカバーするだけの臨時便サービ スが総数として提供されなかったことを意味する。なお、 重称て注意が必要なのは、分母の潜在航空旅客数は途絶 によるトリップの取りやめや他モードへの変更も含めた 総量であるため、表一 2 の各欄の值が100\%に近くなれば 正確な交通需要予測ができたという性格の分析を行って いるのではない。この結果から次のようなことがいえる。 1)潜在負荷を満たすだけの臨時便設定がなされているO Dは少なく、ほとんどの空港間で座席充足率は100\%以 下の数值となっている。すなわち、潜在航空負荷に対 して十分な機材が準備できず、また航空需要も顕在化 しない部分も多かったということが推察できる。

2) 東京・高松間や名古屋・山口宇部間など、潜在航空旅 客による負荷が存在するにも関わらず、臨時便が設定 されなかった航路も多い。機材スケジューリングや採 算などの面で限界があったことが伺える

3)東京・岡山便の座席充足率は $121 \%$ となっているのに対 し、東京から岡山以外一の空港便の座席充足率は軒並 み $100 \%$ 以下の值を示している。このことから、東京か ら途絶で隔てられた地域の東端に位置する岡山へ重 点的に航空機が運行されていたことが伺える。

4)これに対し大阪発着では、通常時に航空便が設定され ていない岡山便も臨時便として設定されている。しか し、大阪・岡山間は近距離であるがゆえに在来線や道 路などで迁回アクセスすることも多いことが考慮さ れた結果か、座席充足率は３０％と低く抑えられてい る。同様に、船舶でのアクセスが容易な大阪・高松間 も低い座席充足率となっている。これに対して長距離 であるために航空機が交通手段として優位性を持つ 
大阪・福岡間においては相対的に座席充足率が高くな っている。

5)表一 2 の中で特に目立つ数値として、名古屋・熊本間 の317\%があげられる。東京・熊本間や大阪・熊本間の 臨時便が設定されていないことから考えて、それらの 需要もあわせ、東京や大阪に比較して空港容量にも多 少ゆとりのある名古屋便が受け持つようにスケジュ

一ルされたことが考えられる。

以上のように、潜在的な航空旅客を対象に分析を行っ たことで、途絶時における実際のサービスと潜在航空旅 客負荷の間にこれだけの差があることを明らかにするこ とができた。さらに、途絶が生じることにより、現在の 新幹線が運んでいる旅客のうち、どのような部分が航空 旅客サービスによってもカバーが容易ではないかを示唆 することができた。

\section{6. おわりに}

本研究では、新幹線の途絶によって潜在航空旅客に及 ぶ負荷が非常に大きいことを定量的に示寸ことができた。 分析の結果、どこで途絶が生じても、その影響は全国に 及び、特に実人数でみると大都市圏における特定の空港 に負荷が集中することが示された。また、従来の実旅客 数との比で見ると、地方空港により大きな負担がかかる ことが明らかとなった。さらに、実際に途絶が生じた阪 神大震災時の臨時便データを収集し、座席充足率という 観点から潜在的な負荷がどの程度受け止められているか を実証的な観点から検討した。この結果、機材等のスケ ジューリングの限界から、実際の途絶時には全般的に潜 在負荷以下のサービスしか提供されていなかったことや、 サービスの提供状況が実際の潜在負荷の発生パターンと 比較してかなり偏りがあることを具体的に明らかにする ことができた。

今後の課題として、本研究では実際の途絶時の状況と
こ下各航空会社が提供した臨時便サービスの量のみを検 討している。このため、各航空会社が潜在的な旅客を実 際にどのように想定し、それに対してどのような考えの さとでこのような臨時便のパターンを設定したのかにつ いて、ヒアリングを加えることにより、本研究の有効性 及ご適用範囲を吟味することが望ましい。また本研究で 法、途絶による影響を被った人間をすべて等ウェイトで 分析上扱っているが、現実的には各個人が受ける影響は そのトリップの目的やOD及び個人属性によっても異な るはずであり、それらの重み付けをどのように考えるか という点についても今後の検討が必要である。

本研究では運輸政策研究機構より幹線旅客純流動調査 (承認番号11442)を、航空各社より臨時便データのご提供 をいただいた。記して謝意を申し上げる。

\section{参考文献}

1)たとえば南・高野・佐藤 : 道路網における代替ルート の整備水準の一評価法に関する研究、土木学会論文集、 No.530/IV-30、pp.67-77、1996.

2)たとえば堀・石田 : 震災時の連結信頼性からみた住区 内街路網構成の評価、土木計画学シンポジウム、阪 神・淡路大震災土木計画学調査研究論文集、pp.415-424、 1997.

3)高橋・田中・家田・村木 : 全国交通ネットワークにお ける地震発生リスクのリンク及びリンク交通量への 影響評価、土木計画学研究・論文集、No.15、pp.345-350、 1998.

4)全日本航空事業連合会 : 運輸省航空局監修、航空輸送 統計年報、航空統計年報、1998.

5)浅見均 : 東海道新幹線の長期不通時における社会的損 失の評価、土木計画学研究·講演集、No.23、pp.707-710、 2000.

\section{潜在的な航空旅客負荷にみる新幹線途絶による影響の基礎的検討}

谷口守・阿部宏史・清水健夫 コンクリート塊の落下など、新幹線は施設全体のリニューアルまで考虑すべき時期にあるが、その地域間交 通に占める重要性という観点からの議論は乏しく、サービス途絶時の影響に関する冷静な議論がない。本研究 では幹線旅客純流動調査のデータから、7カ所の想定ポイントで途絶した場合に生じる影響を、潜在的な航空 旅客負荷に換算することで検討した。分析から潜在旅客負荷は大きく広範に及び、特定空港に集中するととも に、現状に比すれば地方部の負荷も大きいことが示された。また、実際に新幹線の途絶が発生した阪神大震災 時の航空臨時便データとの比較から、実際のサ一ビス提供が負荷の解消には至っていないことを明らかにした。 


\section{Basic study on latent air passenger demands caused by stopping of the Shinkansen}

By Mamoru TANIGUCHI, Hirofumi ABE and Takeo SHIMIZU

It has already passed 37 years since the beginning of the Shinkansen service. Though the renewal of Shinkansen might be necessary in near future, the influence caused by stopping of Shinkansen had not investigated. This study aims to calculate the load caused by stopping, as the number of latent air passenger demands. 7 points on the Shinkansen line have assumed to be cut off, and latent air passenger demands in each case is calculated. The results show that the total pressure of latent demands is very large. Not only metropolitan airports, but also local airports would suffer its burden. Moreover, the temporal air service data by the Hanshin Great Earthquake (1995) is adopted for the case study. It is also clarified that temporal air service at that time could not cover the latent air passenger demand caused by stopping of the Shinkansen. 